\title{
Measuring Success in Small Family Businesses - A Socioemotional Wealth Perspective
}

\author{
Ivana, Bujan \\ Polytechnic of Međimurje in Čakovec, Croatia
}

\section{Abstract}

The goal of this paper is to reveal typical non-financial success measures in small family business in Croatia. Socioemotional wealth model is used as a basis for questionnaire construction. Questionnaire items represent family typical success measures and are adaptable to different business activities. Since family business is heterogeneous it was necessary to give a definition of chosen sample - small family hotels. Given definition of small family business was used as a key to separate the family and non-family businesses in this survey. Chosen, socioemotional based, success measures were tested on a sample of small family hotels by using logistic regression. Based on the statistical results, community acknowledgments and continuation of family business are the most important non-financial success measures for Croatian example.

Keywords: family firm management, family entrepreneurship, socioemotional wealth JEL classification: D10, L25, L26, M21

\section{Introduction}

In order to capture heterogeneous characteristics of small family businesses, researches tend to analyse these businesses from various perspectives: business issues, education, performance, strategic planning and entrepreneurship (Chaston, 2012; Cleveland et al., 2007; Kushi and Caca, 2010; Machek and Hnilica, 2014; Peters et al., 2009). These perspectives are just a rough overview for the purposes of this introduction, whereby usually they are much more diverse and often overlap. Heterogeneity stems from differences regarding business activities, sizes, ownership structures, generation of family business, etc. Due to the importance of tourism in Croatia, the types of small family hotels and small family businesses in tourism in this research are particularly fruitful for an analysis (Ivandić and Šutalo, 2018; Perić and Nikšić, 2007).

When one analyses a family business, competitive advantage is to be seen through the lens of specific family performance. Relatively new model of socioemotional wealth (SEW) (Berrone et al., 2012), provides a theoretical basis for the construction of family-specific success measures developed in this study. This model is increasingly interesting for an analysis of many other family firm researchers (Cruz et al., 2011; Deslandes et al., 2016; Duran, 2016; Martínez-Alonso et al., 2018; Shen, 2018). The goals of this research are to:

- establish and analyse financial and non-financial performance measures specific to small family hotels;

- determine what reasons drive the owners to start and set up the business. 


\section{Literature review and hypothesis development}

In small family businesses in tourism and, specifically in small family hotels, nonfinancial family performance can be more important than financial performance. However, hotel-specific financial performance measures are still widely used, particularly in larger businesses, and have to be combined with non-financial measures. Financial performance relates to the sales revenue growth, profit growth, cash flow dynamics, and financial analysis indicators(Al-Dubai et al., 2014; Chaston, 2012; Chinomona, 2013; Cruz et al., 2008; Naldi et al., 2007; Runyan et al., 2008). Other authors analyse hotel performance measures regardless of family ownership, where the findings could be adapted to the family hotels (Phillips and Louvieris, 2005; Sainaghi, 2011; Baloglu et al., 2010; Sainaghi et al., 2013). Many authors discuss the importance of non-financial performance (Berrone et al., 2012; Chua et al., 2015; Kallmüenzer et al., 2018; Kallmüenzer and Peters, 2017, 2014; Kotlar and De Massis, 2013; Zellweger et al., 2013). Non-financial, qualitative criteria for determining nonfinancial performance imply intangible assets, while knowledge is the key factor for success and particularly important component of strategic asset (Vitezić and KnezRiedl, 2005).

The non-financial performance can be derived from the social identity theory and the SEW model. Measuring non-financial performance is often carried out through questionnaires, where family owners or directors' point to the success from their own point of view. Examples of such scales (with 7 values) are statements where respondents are asked to assess profitability, sales, growth, and total business success (Hallak et al., 2014; Hallak and Assaker, 2013; Kropp et al., 2006). Some of the responses were: "My company has been very profitable," "The growth rates are high," or "I'm happy with the company's business performance." For each response there is one value on Likert's scale from 1 to 7 . Another way of testing the nonfinancial performance is an interview, and some typical non-financial indicators for small family hotels that use Bergin-Seers and Jago (2007) are the rate of capacity occupancy, the number of new guests, the number of returning guests, and reports about the overall quality of space.

The social identity theory is closely related to the social categorization theory (van Knippenberg et al., 1994; Tajfel et al., 1984). It serves as a theoretical foundation for operationalizing non-financial, i.e. non-economic performance in small family hotels that include owners and family members in a local community. The whole family identifies itself with the community; in some cases, actively preserves nature, promotes destination, and influences the development of the whole destination, i.e. rural or smaller community. Consequently, community engagement and acknowledgments are an important measure for the success of entrepreneur's/owner's small family hotels (Getz and Carlsen, 2005). Non-financial performance in small family hotels is the owners' desire to fit in the community within they operate. Community engagement presupposes a mechanism when an entrepreneur becomes a part of the local community and gains access to information, with local knowledge representing a possible key factor in achieving profitability (Jack and Anderson, 2002). An entrepreneur involved in the local community can provide authentic experience to tourists based on their own knowledge and through other local contacts. The effectiveness of the involvement process in the community is influenced by local politics and relationships, as well as the owner's personal skills. A place or community, i.e. environment, does not only relate to a physical location, but represents a holistic phenomenon that includes spatial, social, psychological, and temporal processes (Harris et al., 1996). Choices of 
environment affect future goals, business practices, and long-term strategies for small business owners in tourism (Hallak and Assaker, 2013).

Further discussion on non-financial performance cannot be expanded without mentioning the SEW model which is the primary topic of this paper. The model finds its origin in the stewardship theory and the behavioural agency theory, and was originally developed by Berrone et al., (2012); Cennamo et al. (2012); Gómez-Mejia et al. $(2011$, 2007). The model was developed as a response to often contradictory empirical results in family business research, excessive reductionism, overlapping terminology, and fragmentation of theoretical basis (Berrone et al., 2012, p. 258). According to the authors, SEW is a set of values that a family derives from family ownership and relates to transfer of ownership to other family members, ensures employment for family members, and develops family reputation. Authors of the model also propose construct samples for measuring SEW called FIBER (Family Control and Influence, Family Members' Identification with the Firm, Binding Social Ties, Emotional Attachment, Renewal of Family Bonds to the Firm Through Dynastic Succession). SEW variable, transferring family business to future generations is actually one of the feature that defines and differentiates family business from nonfamily, which further suggests a need to adopt a long-term family business strategy (Chua et al., 1999). Consequently, long-term strategies and long-term goals can help families to establish and realize non-financial goals (Chrisman et al., 2012). The longterm orientation of family work, the continuation of family tradition, and the transfer of ownership to family members are currently drawing attention of many scientists dealing with family entrepreneurship, with detected lack of research in that area (Carr et al., 2016; Veider and Kallmüenzer, 2016; Zellweger et al., 2011). Variables regarding performance are still not sufficiently operationalized and are tested with missing time component in order to achieve continuity when bringing empirical conclusions (Sharma et al., 2014). Contribution of this research can be found in development and proposal of performance constructed for small family hotels. Authors suggest to test these measures on other samples.

On the basis of literature review the following hypotheses are developed to test the influence of SEW specific variables in family business:

H1. Owner-specific motives have a significant impact on the continuation of the small family hotels

H2. The specific entrepreneurial knowledge of the owner, acquired through additional education, significantly influences the non-financial performance of small family hotels

\section{Methodology}

For purposes of this research, a structured questionnaire was composed, based on questionnaires from other authors who proved validity of the respective constructs/statements amended with own constructs (Bezzina, 2010; Fisher and Koch, 2008; Hatak et al., 2016; Kallmüenzer and Peters, 2014; Lumpkin and Dess, 2001; Miljković Krečar, 2008; Wiklund and Shepherd, 2003; Zellweger et al., 2012). The constructs/statements in the questionnaire make variables in the research model. The questionnaire also contains suggestions of non-financial performance and SEW components.

Two statistical models were developed. Statistical program for data analysis used was SPSS 20 and Eviews. Logistic binary regression was employed for the binary dependent variables (community acknowledgment and continuation of family business. 
Independent SEW variables resulting from the structured questionnaire are divided into three groups: knowledge and experience of small family hotel owners, entrepreneurial attributes of small family hotel owners, and motives for entering the family business (Table 1).

Table 1

Independent Variables List

\begin{tabular}{|c|c|c|c|}
\hline Variable title & Abbreviation & Measurement type & Code \\
\hline $\begin{array}{l}\text { Education before work } \\
\text { in own company (1) } \\
\text { and education during } \\
\text { work in own company } \\
\text { (2) }\end{array}$ & $\begin{array}{l}\text { EDU } 1 \\
\text { EDU } 2\end{array}$ & $\begin{array}{l}\text { Offered education types } \\
\text { (multiple choice). }\end{array}$ & $0-1$ \\
\hline $\begin{array}{l}\text { Motives regarding } \\
\text { business entry (setting } \\
\text { up own business) }\end{array}$ & MOTIV & $\begin{array}{l}\text { If owners chose one or } \\
\text { more education types, } \\
\text { the answer was coded } \\
\text { with } 1 \text {, otherwise } 0 .\end{array}$ & $1-5$ \\
\hline
\end{tabular}

Source: Authors' work

Dependent variables in the model are non-financial performance measures continuation of family business (binary variable, yes/no) and community acknowledgments of owners (binary variable, important/not important). List of dependent variables can be found in Table 2.

Table 2

Dependent Variables List

\begin{tabular}{lllc}
\hline \multicolumn{1}{c}{ Variable title } & Abbreviation & \multicolumn{1}{c}{ Measurement type } & Code \\
\hline $\begin{array}{l}\text { Continuation of family } \\
\text { business }\end{array}$ & CONT_F & $\begin{array}{l}\text { Offered } \\
\text { yes/no/already } \\
\text { continued }\end{array}$ & answers: \\
Community & COMM_A & $\begin{array}{l}\text { Offered answers: yes/no } \\
\text { acknowledgments }\end{array}$ & $0-1$ \\
\hline
\end{tabular}

Source: Authors' work

The inconsistency of the conceptual definition for the small family businesses in tourism prevents systematic, statistic, and empirical monitoring, which results in a better understanding and future development. For the purposes of defining the sample in this paper and to contribute to the family business research corps, the criterion for classifying small family hotels - as a form of small family businesses in tourism - is determined according to the accounting criteria and family characteristics. The accounting criteria is the number of employees, the size of the assets, and the annual income, while the characteristics of the family are: an individual must be a member of the owner's family, and they have to work or/and be employed in a small family hotel with no more than 50 accommodation units.

The research sample consists of business entities, members of the National Association of Family, and Small Hotels in Croatia. The sample was limited to these units due to its representativeness and ensuring validity of the statistical tests. In Croatia there is no data registry or data base for small family businesses in tourism or hotels. Therefore, the sample for the statistical analysis has been set to $120(N=120)$.

In the second part of the analysis, structured questionnaires were sent to the sample, small hotels. 85 out of 120 units have been sufficient to run the statistical tests 
- the multiple and logistic regression and hypothesis testing (Bahovec and Erjavec, 2009; Baron and Ward, 2004; Tkalec Verčić, 2013).

\section{Research Results}

In the first model it will be tested how owner's motivation to enter family business impacts non-financial performance measure continuation of family business.

Hosmer and Lemeshow is significant at 0.29 and correctness of the model is measured with Nagelkerke R2 (0.240) and Cox\&Snell R2 (0.29) values, which shows good predictive power of the model. Referent values in the model are continuation of the family business coded with number 1 . Model correctly specifies $76.67 \%$ of the dependent variable community acknowledgments assessment results. Probability ratio tested on mutual parameters restriction produces LR test of 15.23 with $p=0.009$, which points to the overall good fit of the model.

Owners of the small family hotels in the sample whose motivation was, during the establishment of their company, to provide a job for family members are 2.28 time more likely to affect the continuation of family business compared to those owners who were not motivated. Owners of the small family hotels in the sample whose motivation was, during the establishment of their company, to keep family in business are 2.95 more likely to affect the continuation of family business compared to those who were not motivated. The regression results with dependent variable continuation of family business can be presented as:

$$
\text { CONT_F }=-0.03+0.82 \mathrm{MOTIV} 2+1.08 \mathrm{MOTIV} 5
$$

The hypothesis that presumes the influence of education on performance is confirmed by the second model. Hosmer and Lemeshow statistics is significant at $\mathrm{p}=0.51$. Nagelkerke and Cox\&Snell values are 0.248 and 0.157 . Referent values in the model are community acknowledgments coded with number 1 and additional education during work in own company coded with number 1. The model correctly specifies $85.26 \%$ of dependent variable community acknowledgments assessment results. The probability ratio tested on mutual parameters restriction produces LR test of 9.93 with $p=0.006$, which points to the overall good fit of the model despite the small value of Nagelkerke i Cox\&Snell pseudo R2. The results of regression suggest that there is a significant likelihood that the owner educated during work in their own business has 20.9 times better community acknowledgments than the owner without educated. Significant regression results with dependent variable community acknowledgments are given with the regression equation as follows:

$$
\text { COMM_A }=0.15+3.04 \text { EDU2 }
$$

Table 3

Regression Results

\begin{tabular}{lll}
\hline Independent variables & \multicolumn{1}{c}{$\begin{array}{c}\text { Model 1 } \\
\text { CONT_F }\end{array}$} & \multicolumn{1}{c}{ Model 2 } \\
& \multicolumn{1}{c}{ COMM_A } \\
\hline MOTIV_2 & $0.82^{*}$ & \\
MOTIV_5 & $1.08^{*}$ & $3.04^{*}$ \\
EDU2 & & $0.248^{*}$ \\
Negelkerke R2 & $0.380^{*}$ & $0.157^{*}$ \\
Cox\&Snell R2 & $0.240^{*}$ & 20.09 \\
OR (Odds ratio) & $2.28 / 2.95$ & \\
\hline
\end{tabular}

Note: ${ }^{*}=\mathrm{p}<0.05 ;{ }^{* *}=\mathrm{p}<0.001$

Source: Author's work 


\section{Discussion}

Research results have yielded insights that have theoretical corollaries for the family business in tourism literature related to family entrepreneurship and SEW.

First, the results from this study show that owner's education during work in own hotel positively influences community acknowledgments, meaning the owner communicates better with other stakeholders in the community where they live. This could mean that education improves social skills of the owner. In addition, local family businesses could network, which could provide further benefits on the community level. Networking facilitates family business as found in other research (Vlahov, 2013).

Explorative research was conducted regarding SEW variables - owner's entry motives, community acknowledgments, and continuation of family business. These research results strongly relate to SEW model and its challenges. Motives are very much of emotional nature, where owner sets up a family business with the aim to provide a job for family members and to keep family in the business. Proposed constructs are a methodological attempt to capture part of the SEW components. Authors propose to test and amend outlined model components to obtain deeper insight and understanding of SEW - motivation and non-financial performance, in family firms. Findings could also contribute the business transfer literature.

This study gives nascent proposals of few SEW measures - community acknowledgments (or social embeddedness), continuation of family business (both in model defined as dependent variables) and owner's motives to set up a family business (mentioned in paper as "entry motives" and in model defined as independent variable) on a sample of small family hotels in Croatia. The measures are yet to be tested on family businesses in other countries and various business activities. It is recommended to develop in more detail SEW variables community acknowledgments and continuation of family business, i.e. non-financial performance measures specific to family business and motives for setting up a family business.

Upon conducted research, some limitations were detected. Research limitations include the inability to compare results with other countries since the study is conducted only for Croatia, the owners were reporting desired outcomes compared to the realistic picture in qualitative questionnaires and interviews, and there was only one business activity included in the study (hotel industry).

Guidelines for future research imply further validation of additional constructs and tests regarding entrepreneurial attributes (e.g. locus of control, competitive agreeableness) and knowledge, and further validation of non-financial performance factors offered in this paper. Furthermore, author also recommends to conduct a research in a few years when the analysis could be applied to monitoring the state of a family business in tourism as a long-term endeavour. It would also be interesting to measure proposed SEW and entrepreneurial components on various other family businesses in different sizes and capacities. Finally, author suggests to amend and build additional qualitative measures for non-financial performance.

\section{Conclusion}

The study confirmed the importance of non-financial performance measures on the sample of small family hotels in Croatia. The hypotheses were confirmed where family specific motives of owners when entering the family business significantly influence the continuation of family business and additional education of owners during work in own business significantly influences community acknowledgments. 
Some proposals were given with this study but more effort is needed to further develop SEW based success components in family businesses.

\section{References}

1. Al-Dubai, S., Ismail, K., Izah, K. N., Amran, N. A. (2014), "Family involvement in ownership, management, and firm performance: Moderating and direct-effect models", Asian Social Science, Vol. 10, No. 1), 193-205.

2. Bahovec, V., Erjavec, N. (2009), Uvod U ekonometrijsku analizu. Element d.o.o., Zagreb.

3. Baloglu, S., Erdem, M., Brewer, P., Mayer, K., Sainaghi, R. (2010), "Hotel performance: state of the art", International Journal of Contemporary Hospitality Management, Vol. 22, pp. 920-952.

4. Baron, R. A., Ward, T. B. (2004), "Expanding entrepreneurial cognition's toolbox: Potential contributions from the field of cognitive science", Entrepreneurship Theory and Practice, Vol. 28, No. 6, pp. 553-573.

5. Bergin-Seers, S., Jago, L. (2007), "Performance Measurement in Small Motels in Australia:(Funded by the Sustainable Tourism Co-operative Research Centre)", Tourism and hospitality Research, Vol. 7, No. 2, pp. 144-155.

6. Berrone, P., Cruz, C., Gómez-Mejia, L. R. (2012), "Socioemotional wealth in family firms: Theoretical dimensions, assessment approaches, and agenda for future research", Family Business Review, Vol. 25, No. 3, pp. 258-279.

7. Bezzina, F. (2010), "Characteristics of the Maltese entrepreneur", International Journal of Arts and Sciences, Vol. 3, No. 7, pp. 292-312.

8. Carr, J. C., Chrisman, J. J., Chua, J. H., Steier, L. P. (2016), "Family Firm Challenges in Intergenerational Wealth Transfer", Entrepreneurship Theory and Practice, Vol. 40, No. 6, pp. 1197-1208.

9. Cennamo, C., Berrone, P., Cruz, C., Gómez-Mejia, L. R. (2012), "Socioemotional wealth and proactive stakeholder engagement: Why family-controlled firms care more about their stakeholders", Entrepreneurship Theory and Practice, Vol. 36, No. 6, pp. 1153-1173.

10. Chaston, I. (2012), "Recession and family firm performance: an assessment of small UK family-owned hotels", Journal of CENTRUM Cathedra: The Business and Economics Research Journal, Vol. 5, No. 1, pp. 60-69.

11. Chinomona, R. (2013), "Business owner's expertise, employee skills training and business performance: A small business perspective", Journal of Applied Business Research (JABR), Vol. 29, No. 6, pp. 1883-1896.

12. Chrisman, J. J., Chua, J. H., Pearson, A. W., Barnett, T. (2012), "Family involvement, family influence, and family-centered non-economic goals in small firms", Entrepreneurship theory and practice, Vol. 36, No. 2, pp. 267-293.

13. Chua, J. H., Chrisman, J. J., De Massis, A. (2015), "A closer look at socioemotional wealth: Its flows, stocks, and prospects for moving forward", Entrepreneurship Theory and Practice, Vol. 39, No. 2, pp. 173-182.

14. Chua, J. H., Chrisman, J. J., Sharma, P. (1999), "Defining the family business by behaviour", Entrepreneurship theory and practice, Vol. 23, No. 4, pp. 19-39.

15. Cleveland, J. N., O'Neill, J. W., Himelright, J. L., Harrison, M. M., Crouter, A. C., Drago, R. (2007), "Work and family issues in the hospitality industry: Perspectives of entrants, managers, and spouses", Journal of Hospitality \& Tourism Research, Vol. 31, No. 3, pp. 275-298.

16. Cruz, C., Firfiray, S., Gómez-Mejia, L. R. (2011), "Socioemotional Wealth and Human Resource Management (HRM) in Family-Controlled Firms", in Joshi, A., Liao, H., Martocchio, J. J. (Eds.), Research in Personnel and Human Resources Management, Vol. 30, Emerald Group Publishing Limited, pp. 159-217.

17. Cruz, C., Justo, R., Castro, J. (2008), "Family involvement and firm performance: a family embeddedness perspective, Working Paper, GE8-107-I, IE Business School. 
18. Deslandes, M., Fortin, A., Landry, S. (2016), "Payout differences between family and nonfamily listed firms: A socioemotional wealth perspective", Journal of Family Business Management, Vol. 6, No. 1, pp. 46-63.

19. Duran, P. (2016), "An institutional perspective of the socioemotional-financial wealth relationship", Management Research: Journal of the Iberoamerican Academy of Management, Vol. 14, No. 3, pp. 258-266.

20. Fisher, J. L., Koch, J. V. (2008), Born, not made. The Entrepreneurial Personality, Greenwood publishing group, London.

21. Getz, D., Carlsen, J. (2005), "Family business in tourism: State of the art", Annals of tourism research, Vol. 32, No. 1, pp. 237-258.

22. Gómez-Mejia, L. R., Cruz, C., Berrone, P., De Castro, J. (2011), "The bind that ties: Socioemotional wealth preservation in family firms", Academy of Management Annals, Vol. 5, No. 1, pp. 653-707.

23. Gómez-Mejía, L. R., Haynes, K. T., Núñez-Nickel, M., Jacobson, K. J., Moyano-Fuentes, J. (2007), "Socioemotional wealth and business risks in family-controlled firms: Evidence from Spanish olive oil mills", Administrative science quarterly, Vol. 52, No. 1, pp. 106-137.

24. Hallak, R., Assaker, G. (2013), "Family vs. non-family business owners' commitment to their town: A multigroup invariance analysis", Asia Pacific Journal of Tourism Research, Vol. 18, No. 6, pp. 618-636.

25. Hallak, R., Assaker, G., O'Connor, P. (2014), "Are family and nonfamily tourism businesses different? An examination of the entrepreneurial self-efficacyentrepreneurial performance relationship", Journal of Hospitality \& Tourism Research, Vol. 38, No. 3, pp. 388-413.

26. Harris, P. B., Brown, B. B., Werner, C. M. (1996), "Privacy regulation and place attachment: Predicting attachments to a student family housing facility", Journal of Environmental Psychology, Vol. 16, No. 4, pp. 287-301.

27. Hatak, I., Kautonen, T., Fink, M., Kansikas, J. (2016), "Innovativeness and family-firm performance: The moderating effect of family commitment", Technological forecasting and social change, Vol. 102, pp. 120-131.

28. Ivandić, N., Šutalo, I. (2018), "The contribution of Tourism to the Croatian economy: an IO approach, Ekonomski pregled, Vol. 69, No. 1, pp. 20-42.

29. Jack, S. L., Anderson, A. R. (2002), "The effects of embeddedness on the entrepreneurial process", Journal of business Venturing, Vol. 17, No. 5, pp. 467-487.

30. Kallmüenzer, A., Peters, M. (2017), "Exploring entrepreneurial orientation in family firms: the relevance of social embeddedness in competition", International Journal of Entrepreneurship and Small Business, Vol. 30, No. 2, pp. 191-213.

31. Kallmüenzer, A., Peters, M. (2014), "Entrepreneurial Dimensions in Family Firms: Introducing "Competitive Agreeableness", in the Proceedings of 10th Family Firm Workshop, Bergamo, Italy.

32. Kallmüenzer, A., Strobl, A., Peters, M. (2018), "Tweaking the entrepreneurial orientation-performance relationship in family firms: the effect of control mechanisms and family-related goals", Review of Managerial Science, Vol. 12, No. 4, pp. 855-883.

33. Kotlar, J., De Massis, A. (2013), "Goal setting in family firms: Goal diversity, social interactions, and collective commitment to family-centered goals", Entrepreneurship Theory and Practice, Vol. 37, No. 6, pp. 1263-1288.

34. Kropp, F., Lindsay, N. J., Shoham, A. (2006), "Entrepreneurial, market, and learning orientations and international entrepreneurial business venture performance in South African firms", International marketing review, Vol. 23, No. 5, pp. 504-523.

35. Kushi, E., Caca, E. (2010), "Some problems of the micro, small and medium enterprises in Albanian holiday hotels", Regional Science Inquery, Vol. 2, No. 1, pp. 63-70.

36. Lumpkin, G. T., Dess, G. G. (2001), "Linking two dimensions of entrepreneurial orientation to firm performance: The moderating role of environment and industry life cycle", Journal of business venturing, Vol. 16, No. 5, pp. 429-451. 
37. Machek, O., Hnilica, J. (2014), "Is Substantial Family Influence a Good Measure of Family Involvement? Evidence from the Czech Republic", in the Proceedings of 7th Asia-Pacific Business Research Conference, Singapore.

38. Martínez-Alonso, R., Martínez-Romero, M. J., Rojo-Ramírez, A. A. (2018), "Technological innovation and socioemotional wealth in family firm research: Literature review and proposal of a conceptual framework", Management Research: Journal of the Iberoamerican Academy of Management, Vol. 16, No. 3, pp. 270-301.

39. Miljković Krečar, I. (2008), "Konstrukcija i empirijska provjera upitnika poduzetničkih sklonosti", Psihologijske teme, Vol. 17, No. 1, pp. 57-73.

40. Naldi, L., Nordqvist, M., Sjöberg, K., Wiklund, J. (2007), "Entrepreneurial orientation, risk taking, and performance in family firms", Family business review, Vol. 20, No. 1, pp. 3347.

41. Perić, M., Niksić, M. (2007), "PPP in Croatian tourism: chance for Croatian family hotels", Tourism and hospitality management, Vol. 13, No. 3, pp. 651-664.

42. Peters, M., Frehse, J., Buhalis, D. (2009), "The importance of lifestyle entrepreneurship: A conceptual study of the tourism industry", Pasos, Vol. 7, No. 2, pp. 393-405.

43. Phillips, P., Louvieris, P. (2005), "Performance measurement systems in tourism, hospitality, and leisure small medium-sized enterprises: a balanced scorecard perspective", Journal of Travel Research, Vol. 44, No. 2, pp. 201-211.

44. Runyan, R., Droge, C., Swinney, J. (2008), "Entrepreneurial orientation versus small business orientation: what are their relationships to firm performance?", Journal of Small Business Management, Vol. 46, No. 4, pp. 567-588.

45. Sainaghi, R. (2011), "RevPAR determinants of individual hotels: evidences from Milan", International Journal of Contemporary Hospitality Management, Vol. 23, No. 3, pp. 297-311.

46. Sainaghi, R., Phillips, P., Corti, V. (2013), "Measuring hotel performance: Using a balanced scorecard perspectives' approach", International Journal of Hospitality Management, Vol. 34, pp. 150-159.

47. Sharma, P., Salvato, C., Reay, T. (2014), "Temporal Dimensions of Family Enterprise Research, Family Business Review, Vol. 27, No. 1, pp. 10-19.

48. Shen, N. (2018), "Family business, transgenerational succession and diversification strategy: Implication from a dynamic socioemotional wealth model", Cross Cultural \& Strategic Management, Vol. 25, No. 4, pp. 628-641.

49. Tajfel, H., Fraser, C., Jaspars, J. M. F. (1984), The Social Dimension: Volume 2: European Developments in Social Psychology, 1st edition, Cambridge University Press, Cambridge.

50. Tkalec Verčić, M. (2013), Sektorske analize - turizam, Zagreb.

51. van Knippenberg, A., van Twuyver, M., Pepels, J. (1994), "Factors affecting social categorization processes in memory", British Journal of Social Psychology, Vol. 33, No. 4, pp. 419-431.

52. Veider, V., Kallmüenzer, A. (2016), "Assessing long-term orientation among founderand descendant-led firms", Journal of Family Business Management, Vol. 6, No. 1, pp2-22.

53. Vitezić, N., Knez-Riedl, J. (2005), "The Use of Financial and Non-Financial Measures in Decision-Making Process of Enterprises Performance in a Transition Economy", in the Proceedings of the Sixth International Conference-Enterprise in Transitionn, Sveučilište u Splitu, Split, pp. 57-60.

54. Vlahov, A. (2013), Utjecaj strateškog udruživanja na uspješnost poslovanja malih i obiteljskih hotela, Ekonomski fakultet u Zagrebu.

55. Wiklund, J., Shepherd, D. (2003), "Knowledge-based resources, entrepreneurial orientation, and the performance of small and medium-sized businesses", Strategic management journal, Vol. 24, No. 13, pp. 1307-1314.

56. Zellweger, T. M., Nason, R. S., Nordqvist, M. (2012), "From longevity of firms to transgenerational entrepreneurship of families: Introducing family entrepreneurial orientation", Family Business Review, Vol. 25, No. 2, pp. 136-155. 
57. Zellweger, T. M., Nason, R. S., Nordqvist, M., Brush, C. G. (2013), "Why do family firms strive for nonfinancial goals? An organizational identity perspective", Entrepreneurship Theory and Practice, Vol. 37, No. 2, pp. 229-248.

58. Zellweger, T., Sieger, P., Halter, F. (2011), "Should I stay or should I go? Career choice intentions of students with family business background", Journal of business venturing, Vol. 26, No. 5, pp. 521-536.

\section{About the authors}

Ivana Bujan, Ph.D. is a vice-dean for quality and international relations at the Polytechnic of Međimurje in Čakovec. She received PhD in Family Entrepreneurship at the Faculty of Economics Rijeka. She participated in many Erasmus activities giving lectures and doing job shadowing in Cyprus, Austria, Russia, Israel, Czech Republic, Portugal, and Slovenia. Her main research interest is family entrepreneurship. She is actively engaged in number of projects (EU and national) and develops international cooperation at the Polytechnic. She is also engaged in quality assurance systems at the Polytechnic. The author can be contacted at ibujan@mev.hr. 